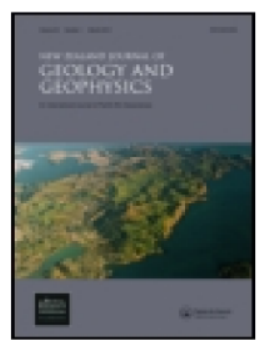

New Zealand Journal of Geology and Geophysics

ISSN: 0028-8306 (Print) 1175-8791 (Online) Journal homepage: http://www.tandfonline.com/loi/tnzg20

\title{
Geophysical imaging of disrupted coastal dune stratigraphy and possible mechanisms, Haast, South Westland, New Zealand
}

\section{Nobes, HM Jol \& B Duffy}

To cite this article: DC Nobes, HM Jol \& B Duffy (2016): Geophysical imaging of disrupted coastal dune stratigraphy and possible mechanisms, Haast, South Westland, New Zealand, New Zealand Journal of Geology and Geophysics, DOI: 10.1080/00288306.2016.1168455

To link to this article: http://dx.doi.org/10.1080/00288306.2016.1168455

曲 Published online: 28 Jun 2016.

Submit your article to this journal

Џll Article views: 6

Q

View related articles $\square$

(Diew Crossmark data ¿ 
Geophysical imaging of disrupted coastal dune stratigraphy and possible mechanisms,

\section{Haast, South Westland, New Zealand DC.}

Nobes $^{\mathrm{a}^{*}}, \mathrm{HM} \mathrm{Jol}^{\mathrm{b}}$ and B Duffy ${ }^{\mathrm{c}}$

a. School of Nuclear Engineering and Geophysics, East China Institute of Technology, No. 418 Guanglan Avenue, Economic Development Area, Nanchang 330013, Jiangxi, China Formerly Department of Geological Sciences, University of Canterbury, Christchurch, New Zealand

b. Department of Geography and Anthropology, University of Wisconsin - Eau Claire, 105 Garfield Avenue, Eau Claire, Wisconsin 57402-4004, USA

c. Terra Search Pty Ltd., 21 Keane Street, Currajong, Queensland, Australia and Department of Geological Sciences, University of Canterbury, Christchurch, New Zealand

* Corresponding author. david.nobes@ canterbury.ac.nz 


\section{Abstract}

Geophysical imaging of coastal dune stratigraphy near Haast, South Westland, provides insight into coseismic dune modification on a seismically active coastline. Ground penetrating radar (GPR) reveals two low-angle features that apparently truncate and offset dune bedding. Complex attribute analysis of the GPR profiles, and a distinct electrical resistivity response, are consistent with truncated bedding. One feature is near-coastal and separates post-seismic dunes that have been attributed to the 1717 and 1826 Alpine Fault earthquakes. Another is inland, and coincident with a stream channel. Superficially, the truncations might be interpreted as erosional features caused by large storms; however, the truncating features penetrate and appear to disrupt the wave base. We thus suggest the near-coastal truncation is either a translational feature, such as a slide, or more likely an erosional record of the 1826 South Westland tsunami. The inland feature records a previous event whose cause needs further investigation.

Keywords: ground penetrating radar, coastal dune, retreat scarp, tsunami, South Westland Abstract Word Count: 147. Total Word Count: 6,026

\section{Introduction}

Tectonic forces are major drivers of landscape evolution, and of range-front and coastal sedimentation in New Zealand and elsewhere (e.g., Goff and McFadgen 2002; Wells and Goff 2006, 2007; Quigley et al. 2007), generating secondary fault ruptures, landslides, and tsunamis. Tsunamis commonly contribute to a cascade of seismotectonic hazards along convergent plate boundaries (Atwater 1987; Goff \& McFadgen 2002; Patton et al. 2009; Fritz et al. 2012) and may be an agent of substantial erosion, entraining near-shore sand, sometimes to well below wave base (Srinivasalu et al. 2007; Goff et al. 2009). The coastal plains of the southwest South Island of New Zealand lie within a few 10s of km away from the Australia-Pacific plate boundary, which has ruptured along the Alpine Fault approximately every 329 years for over 


\section{Nobes et al.}

8000 years (Berryman et al. 2012). Earthquakes on the southwestern end of the Alpine Fault, where it passes offshore, give rise to a tsunami hazard that may be difficult to identify and quantify, even for historic events (e.g., Goff et al. 2004).

Major seismic events can also be responsible for rapid geomorphic evolution, due partly to sediment generation during co-seismic landsliding (Goff and McFadgen 2002; Wells and Goff 2006, 2007; Robinson and Davies 2013; Howarth et al. 2012). Post-seismic sedimentary response can be rapid, and in areas that experience intense runoff events, the post-earthquake residence time of landslide sediment may be of the order of only a few years (Wang et al. 2015) to decades (Howarth et al. 2012). Together, the sedimentary response, landslide effects, and tsunami generation can drastically alter the landscape by cycles of erosion and accretion of sediment at beaches and other coastal features (Goff et al. 2009). A number of studies have concluded that large Alpine Fault events result in large pulses of sediment (e.g. Berryman et al. 2012; Clark et al. 2013; Howarth et al. 2012), which are efficiently delivered to the catchments during large rainfall events (Fitzsimons et al. 2013). Coastal areas of these catchments record the large rainfall, landslide, and faulting events as pulses of sediments that are redistributed by long-shore transport and then by wave and wind action to form coastal dunes, which are subsequently populated by trees and shrubs within decades of an event (Wells and Goff 2006, 2007). Wells and Goff (2006) have used tree rings to relate shoreparallel dunes near Haast to major ruptures on the Alpine Fault. They related the youngest dune to the 1826 Fiordland earthquake, which presumably ruptured on the offshore Puysegur section of the Alpine Fault (e.g., Norris and Cooper 2001). However, Goff et al. (2004) indicate that the tsunami inundation may have extended (Fig. 1) from Dusky Sound in the south, at least to Okarito Lagoon in the north, indicating that it may have caused coastal erosion along the Haast coast. While the record is far from certain, we will follow the timeline and dating outlined by Wells and Goff (2006) as a guide to the shore-parallel morphology. 
Subsurface imaging of disrupted stratigraphy, South Westland, New Zealand

Our initial purpose was thus to investigate the coastal dune stratigraphy and test whether the observed subsurface stratigraphy fit with the Wells and Goff model of dune formation.

Most West Coast sediment pulses incorporate more magnetic sediments (Fitzsimons et al. 2013), which will yield good reflections in ground penetrating radar (GPR) (e.g. Meyers et al. 1996; Smith et al. 1999).

We report the results of our analysis of new GPR and complementary electrical imaging (EI) data from two sites in South Westland, near Haast. The radargrams reveal dune sequences building seaward on top of the interpreted basal wave base platform and on previously deposited dune sequences as we expected to see, and as observed, for example, by Meyers et al. (1996), Smith et al. (1999), and Peterson et al. (2010). In some cases, these could be interpreted as storm event erosional features, or retreat scarps (e.g. Meyers et al. 1996; Peterson et al. 2010) but in others, the truncating features extend to the wave base, and at two sites appear to disrupt the wave base. Strong storms are not known to disturb or disrupt the wave base. One location was near the Haast River mouth, where we observe truncated bedding on the face of the second youngest coastal dune, and the other was inland, crossing an old access track and coincident with a steeply incised stream channel. The age constraints provided by the dune vegetation suggests that the disruption of the wavebase reflection, which superficially resembles low angle faulting, is caused either by low-angle slope failure or by tsunami erosion of the dune face, possibly during the elusive 1826 tsunami.

\section{Site Description and Survey Methodology}

The Alpine Fault is located less than $10 \mathrm{~km}$ to the southeast of the study sites (Figs. 1 and 2). A second large tectonic feature, the South Westland Fault Zone (SWFZ), lies a similar distance to the northwest of the study area, offshore of Haast (Fig. 2). Its activity and recurrence are unknown, but it has been presumed to be inactive in recent times (e.g. 
DC Nobes et al.

Sutherland 1996; Sircombe and Kamp 1998; Rattenbury et al. 2010). The Alpine Fault generates coseismic landslides that provide pulses of sediments to the local catchments (e.g. Howarth et al. 2012; Clark et al. 2013). These sediments are then transported to the Tasman Sea (Figs. 1, 2, and 3), where they are distributed by longshore drift, accreted to the shore face, and form linear shore-parallel beach ridges in the decades immediately following a major Alpine Fault event (Wells and Goff 2006, 2007). By using tree ring dating, each ridge has been attributed to an Alpine Fault event (Fig. 3A).

We investigated two sites: one near the Haast River mouth, in South Westland, New Zealand, and a second half-way between the mouths of the Haast and Okuru Rivers, along an old access track that starts next to the Haast landfill road entrance (Figs. 2 and 3). We used GPR and electrical methods at the sites along the shorter shoreward line (Fig. 3A, short line adjacent to the shore), and GPR alone along the Haast landfill road (Fig. 3B), and the longer Haast Highway (Fig. 3A) profiles. The shoreward profile extended northwest towards the sea from the highway, whereas the road profiles extended inland to the southeast. Other profiles marked in Figure 2 were not used because they were either dominated by recent river erosion and deposition, or were adversely affected by sea water along the shore.

$G P R$

Ground penetrating radar (GPR) has become a widely used tool in subsurface imaging. The reader is referred to Davis and Annan (1989) and Milsom and Eriksen (2011) for descriptions of how GPR works.

The GPR data were gathered using a Sensors \& Software pulseEKKO 100A system, equipped with 50 and $100 \mathrm{MHz}$ antennas. The $50 \mathrm{MHz}$ profiles were acquired by stepping the antennas along the profile at $0.5 \mathrm{~m}$ intervals. This was close to the lateral sampling resolution of the antennas, which is equal to the optimal trace spacing. The $100 \mathrm{MHz}$ GPR profiles were acquired mounted on a sled which was towed slowly, with regularly spaced fiducial markers 
Subsurface imaging of disrupted stratigraphy, South Westland, New Zealand

placed along the line to check the speed and to allow later interpolation to regular trace spacing. The $100 \mathrm{MHz}$ profiles were generally slightly oversampled, which yields good continuity of reflections and of any subsurface diffractions. Both sets of antennas were used at the Haast River mouth (HRM) site. The depth of penetration of the $100 \mathrm{MHz}$ signal is almost as good as for the $50 \mathrm{MHz}$ signal, and the resolution is better, so only the $100 \mathrm{MHz}$ antennas were used for the Haast Highway and Haast landfill road profiles.

In addition to the standard common offset profiles, common mid-point/wide-angle reflection and refraction (CMP/WARR) profiles (Davis and Annan 1989; Hatton et al. 1986) were acquired at the HRM site (Figs. 3A and 4A). Reflection parabolas are generated in the CMP profiles as the source and receiver antennas are separated in a step-wise fashion (Fig. 4A). Semblance analysis of the CMP parabolas (Hatton et al. 1986) allows us to construct a velocity stratigraphy (Fig. 4B). The velocities obtained are consistent with partly saturated to saturated sand and silt: decreasing from about $0.09 \mathrm{~m} / \mathrm{ns}(90 \mathrm{~m} / \square \mathrm{s})$ near the surface to about $0.07 \mathrm{~m} / \mathrm{ns}$ $(70 \mathrm{~m} / \square \mathrm{s})$ at depth. Thus a velocity of $0.07 \mathrm{~m} / \mathrm{ns}$ was used for processing the HRM profiles. The few diffractions due to subsurface scattering features present in the Haast profiles are consistent with the semblance analysis velocities. The weather in the days immediately preceding the acquisition of the Haast shore profiles was very wet, with widespread flooding, and because of the dominance of the water content on the GPR response, the GPR velocity can be affected. The CMP profiles were gathered on the first dry day.

No CMP/WARR profiles could be gathered at the Haast landfill site because of time and spatial constraints. However, there were diffractions present, and the velocities obtained were of the order of $0.1 \mathrm{~m} / \mathrm{ns}(100 \mathrm{~m} / \square \mathrm{s})$, a value more consistent with partly saturated sand. The difference between the Haast shore and Haast landfill road velocities may be due, in part, to the sunny warm weather in the days preceding the acquisition of the Haast landfill profile.

The profiles were further processed using complex attribute analysis (see Hatton et al. 


\section{Nobes et al.}

1986; Kanasewich 1981). Each profile is composed of a set of real numbers - traces - that are a record of the antenna voltage as a function of time, $\mathrm{V}(\mathrm{t})$. If we take the Hilbert transform of each trace, $\mathcal{H}(\mathrm{V}(\mathrm{t}))$, we can create a complex number: $\mathrm{z}(\mathrm{t})=\mathrm{V}(\mathrm{t})+i \not{H}(\mathrm{~V}(\mathrm{t}))=\mathrm{x}+i \mathrm{y}$, where $i=\sqrt{ }-1$, which will then have the usual complex attributes of: instantaneous amplitude (also called the envelope), $|\mathrm{z}(\mathrm{t})|=\sqrt{ }\left(\mathrm{x}^{2}+\mathrm{y}^{2}\right)$, instantaneous phase, $\mathrm{\square}(\mathrm{t})=\tan ^{-1}(\mathcal{H}(\mathrm{V}(\mathrm{t})) / \mathrm{V}(\mathrm{t}))=\tan ^{-1}(\mathrm{y} / \mathrm{x})$, and instantaneous frequency, $f(\mathrm{t})=(\mathrm{d} \square / \mathrm{dt}) / 2 \mathrm{D}$.

The envelope, or instantaneous amplitude, reflects changes in reflection strength, and is often associated with changes in lithology and sequence boundaries (Taner et al. 1979; Taner 2001). The instantaneous amplitude may thus be associated with depositional environment changes. Because of reflection strength variations, the instantaneous amplitude may also change at discontinuities, such as faults. The instantaneous phase is useful for testing the continuity or connectedness of what are apparently continuous reflections (e.g., Yetton and Nobes 1998). Reflections from bedded sediments can often appear continuous and connected even if they are actually offset in the presence of faulting, particularly if no rotation occurs across the fault. The instantaneous phase helps to identify discontinuities in bedding across, for example, faults and unconformities. The instantaneous frequency is often used as an indicator of textural changes (e.g., Francké and Nobes 2000). As such, it has less of a role here, because the textures of dune sediments are similar on both sides of any faults or storm scarps.

\section{Electrical Imaging}

Electrical imaging (EI) profiles were acquired using a Campus Tigre system with 128 electrodes, deployed at $1 \mathrm{~m}$ spacing in a simple Wenner array geometry (e.g., Milsom and Eriksen 2011). The EI profiles were gathered across the youngest coastal dunes near the Haast River mouth (at the shore in Fig. 3A). The HRM profile began on the back of the dune that is 
attributed to the 1717 Alpine Fault earthquake (Fig. 3A) and extended 127 m, finishing at the edge of the high tide mark on the beach just north of the HRM.

The data were modelled using the inversion algorithm developed by Loke and Barker (1996) and implemented in the Res2DInv computer modelling and inversion programme. The measured

EI response is iteratively modelled, until the model converges to a level of "misfit" that is unchanging; the "misfit" is the difference between the measured and model responses, expressed as a root-mean squared error in percent. Each profile thus yielded a "best fit" model that minimised the misfit between the observed apparent resistivities and the model response. Features will be more reliable in the interior of a model than at its edges, because there is less data coverage at the base and at either end of the profile. The models were run with and without topography. The topographically-corrected models were then interpreted jointly with the GPR results.

Figure 5 provides an example of a good fit between the measured (Fig. 5A) and the modelled responses (Fig. 5B) for the HRM EI, with a misfit of only $1.3 \%$. The model which includes topography (Fig. 5C) clearly shows the resistive surface layers, especially the highly resistive dunes, and the contrasting more conductive subsurface layers. The electrical images did not extend far enough out onto the tidal shore to record the influence of sea water at depth, but clearly show the contrast between the dunes on the surface and the deeper strata.

\section{Results}

We now consider the profiles moving from north to south, starting with the Haast Highway profile. All profiles have been migrated and corrected for topography. Examples of the sorts of features we expected to see are illustrated in a portion of the Haast Highway GPR profile. The features of interest are difficult to see in the entire profile, so only a small portion is shown here 


\section{Nobes et al.}

as an example (Figure 6). We observe the GPR reflections from a dune sequence onlapping the seaward slope of a previous dune sequence. The wave base can just be seen at the far left of Figure 6A, at about 350 to $400 \mathrm{~ns}$ two-way travel-time (TWT), or about $8 \mathrm{~m}$ below sea level at this location. A possible storm beach can be seen at the top of the dune sequence, at about 400 $\mathrm{m}$ along the Haast Highway profile. At about $560 \mathrm{~m}$ along the profile, there appear to be truncations of the bedding (arrows in Figure 6), but the truncating feature does not reach the wave base. We interpret this as either a storm beach or possibly a slump feature, given the hummocky character of the material at depth seaward of the arrows.

In contrast, a truncating feature visible across the middle of the Haast shore profiles (Figure 7, highlighted by the dashed line and the arrows) truncates or cross-cuts not only the bedding, but also appears to disrupt the wave base at about 300 - 350 ns two-way travel-time (TWT) or about $8-9 \mathrm{~m}$ below current sea level at this location. This would not occur if the linear feature were merely a wave or storm scarp. The slope of the wave base is disrupted and appears to tilt shoreward at a location that coincides with the truncating feature.

The truncating feature is clearest in the $50 \mathrm{MHz}$ profile (Fig. 7B). The difference in response is further emphasised by the envelope (Fig. 8) and the instantaneous phase (Fig. 9), which makes the offsets clearer in the $100 \mathrm{MHz}$ profile (Figs. 8A and 9A). It is probably not a slump feature, because we do not see any of the hummocky reflections that are characteristic of slumps. The truncating feature is only just visible in the instantaneous frequency profile (Fig. 10), which illustrates that the textures across the truncating feature are similar, and the response is dominated by the sandy lithology.

The clear evidence for a truncating and potentially offsetting feature in the GPR data, is enhanced by comparing the GPR and EI results (Fig. 11), which complement and support each other. The higher resistivity feature (brighter colour) at depth in the EI profiles, is truncated by the dipping GPR reflector. Using the migrated and topographically corrected GPR profiles, 
we estimate the dip of the truncating feature to be about $12^{\circ}$ to $20^{\circ}$ to the northwest. The slope looks much steeper in the GPR profiles due to the vertical exaggeration. The mutual agreement of the two data sets then gives us more confidence in each of the individual data sets.

The Haast landfill road (HLR) profile shows both dune-like features in the near surface (Figure 12A), and indications of massive bedding (i.e. lack of reflections, cf. Nobes et al. 2001) both in the near surface (between about 480 to $540 \mathrm{~m}$ along the profile) and at depth (at about $120 \mathrm{~m}$ along the profile). Closer examination of the HLR profile on either side of the stream channel (Figure 12B) reveals apparent truncations of beds to the northwest (left) of the stream channel. As for the HRM profile, the truncating feature appears to be dipping to the northwest. Complex attribute analysis of the HLR profile (Fig. 13) clarifies the truncating feature, especially in the instantaneous amplitude (Fig. 13A), whilst the lack of continuity of the bed reflections is clearer in the instantaneous phase (Fig. 13B). The instantaneous amplitude (Fig. 13A) also reveals the presence of another, oppositely dipping feature to the southeast (right) of the stream channel. The northwest dipping feature extends to depth, and may offset the wave base, although the reflection energy at that depth is not sufficient to be clear. The southeast dipping feature does not appear to extend to depth much beyond about $4 \mathrm{~m}$, but it has significant envelope energy, and separates two zones, one with little or no envelope response and another with significant envelope response. Both the significant dipping features that are clear in the instantaneous amplitude come to the surface at the stream channel.

\section{Discussion}

We observe several clear truncations of beds in the geophysical imaging profiles. Bending-moment normal faults can be present in this tectonic context. However, the dips of the truncating features are less than $20^{\circ}$, and thus are unlikely to be normal faults. The exact angle of a normal fault depends on the friction angle of the material. Dry sand has a friction angle of 


\section{Nobes et al.}

approximately $30^{\circ}$, so the normal faulting should occur at about $30^{\circ}$ to the (vertical) maximum compressive stress. This suggests that a normal fault in sand should be dipping $\square 60^{\circ}$.

Lower angle failure planes generally require pre-existing structures, high pore pressures, or both. For instance, sliding can occur on low angle failure planes due to high pore pressures (e.g. Hubbert and Rubey 1959). Thus, the anomalous feaures could be a lateral-spread feature, with sliding towards a free face on a low-angle slip surface due to co-seismically elevated pore pressures. In either case, the event that caused the displacement could be coincident with the earthquake that built the seaward, 1826 dune. The beds on either side of the truncating features are difficult to correlate, suggesting that the features are not slip-planes that are offsetting the dune and near-shore stratigraphy. However, difficulty in correlating beds is not the same as a complete lack of correlation. We would also expect to see an indication of a hummocky reflection profile above the wave base, if the bed truncations are due to a slip, as we noted in Fig. 6 for the Haast Highway profile. The response as depth is not clear enough to distinguish if the beds are hummocky or not. We therefore consider a failure surface to be a possible explanation for these features.

We return then to the 1826 earthquake, and the report of a tsunami associated with that event (Goff et al. 2004). The dipping feature in the HRM profile truncates beds that are part of the 1717 dune (Fig. 17), which in 1826 would have been the most seaward dune. A tsunami cutface would, in one sense, be an extreme case of a storm cut beach. As noted earlier, storm cut beaches are not known to disrupt or displace the wave base. The timing would fit what we observe: the feature truncates the beds of the dune associated with the 1717 Alpine Fault event; the beds on either side do not align, but appear to be independently deposited; the seaward beds build up on the base; and subsequently a coastal dune forms that has been attributed to the 1826 event (Wells and Goff 2007). 

foreslope deposits (labelled A in Fig. 17) were eroded and truncated by a tsunami generated by the 1826 Fiordland event, or were truncated by a co-seismic low-angle failure. Some of the material eroded from A was deposited soon after at the base of the slope (B in Fig 17). Sediments transported alongshore during the aftermath of the 1826 event were deposited, initially as coastal dune foresets (Bi in Fig. 17). Most of this sediment would have been shoreface deposits filling the "void" that remained after the tsunami erosion. Continuing cycles of sediment accumulation (C, D and E in Fig. 17) built up the coastal dune deposits, culminating in the foreslope shore accretion (F in Fig. 17). Finally, plants became established on the seaward dune (Wells and Goff 2007).

The other similar feature that we observed along the inland HLR profile are suggestive of a similar process, but associated with an earlier event. The deposits lying seaward of the stream cut are truncated by a feature similar to that observed in the HRM profiles. However, the presence of an additional shallowly dipping feature landward of the stream cut presents the possibility of another tectonic feature controlling the landscape and processes at this site. Given the position of the stream cut, the event predates 1717 , and possibly predates 1615 , based on the dating of Wells and Goff $(2006,2007)$. The site is accessible, albeit from a rough track through West Coast temperate rain forest, and future work could determine the exact nature and timing of the event that gave rise to the truncating feature.

\section{Conclusions}

Geophysical imaging of the beach ridges near the mouth of the Haast River reveals the presence of a linear feature that appears to truncate the bedding in the nearshore dunes and to disrupt the wave base, which we would not expect if it were simply a storm scarp. A similar feature is observed to truncate beds along an old access road adjacent to the Haast landfill road, and there 
DC Nobes et al.

is an incised stream channel where this feature comes to surface. The dips are too shallow and the field relationships indicate that the features are too young to be normal faults, so we suggest that the truncations are likely due to erosion either by a shallowly dipping slip triggered by an event on the nearby Alpine Fault or by a tsunami associated with the 1826 Fiordland earthquake. Given how close the structures come to the surface, it may be possible to test our hypotheses by trenching or other similar means.

\section{Acknowledgements}

We thank Brittany Charlton, Nick Jaeger, and Nick Topper for their invaluable field assistance. They worked tirelessly and well. The project was funded by the University of Wisconsin-Eau Claire International Fellows Program and supported by the Department of

Geography and Anthropology, University of Wisconsin-Eau Claire, and the Department of Geological Sciences, University of Canterbury. We thank the reviewers for their constructive comments which helped improve the manuscript.

\section{References}

Anderson, EM 1951. The Dynamics of Faulting. Edinburgh, Oliver and Boyd. 206 p.

Atwater, BF 1987. Evidence for great Holocene earthquakes along the outer coast of Washington State. Science 236: 942-944.

Berryman, KR, Cochran, UA, Clark, KJ, Biasi, GP, Langridge, RM, Villamor, P 2012. Major earthquakes occur regularly on an isolated plate boundary. Science 336: 1690-1693.

Clark, KJ, Cochran, UA, Berryman, KR, Biasi, G, Langridge, R, Villamor, P, Bartholomew, T, Litchfield, N, Pantosti, D, Marco, S, Van Dissen, R, Turner, G, Hemphill-Haley, M 2013. Deriving a long paleoseismic record from a shallow-water Holocene basin next to the Alpine Fault, New Zealand. GSA Bulletin 125 (5/6): 811-832. 
Subsurface imaging of disrupted stratigraphy, South Westland, New Zealand

Davis, JL, Annan, AP 1989. Ground penetrating radar for high-resolution of soil and rock stratigraphy. Geophysical Prospecting 37: 531-551.

Fitzsimons, SJ, Howarth, JD, Upton, P, Koons, PO 2013. High magnitude, low frequency rainfall events drive landscape development in the Southern Alps. In: Reid, CM, Wandres, A eds. Abstracts, Geosciences 2013 Conference, Christchurch, New Zealand. Geoscience Society of New Zealand Miscellaneous Publication 136A. P. 32.

Francké, J, Nobes, DC 2000. A preliminary evaluation of GPR for nickel laterite exploration. In: Noon, DA, Stickley, GF, Longstaff, D eds. GPR 2000: Proceedings of the 8th International Conference on Ground Penetrating Radar. Society of Photo-Optical Instrumentation Engineers (SPIE) 4084, 7-12.

Fritz HM, Phillips DA, Okayasu A, Shimozono T, Liu H, Mohammed F, Skanavis V, Synolakis CE, Takahashi T 2012. The 2011 Japan tsunami current velocity measurements from survivor videos at Kesennuma Bay using LiDAR. Geophysical Research Letters 39(7): L00G23.

Goff JR, Lane E, Arnold J 2009. The tsunami geomorphology of coastal dunes. Nat. Hazards Earth Syst. Sci. 9(3): 847-854.

Goff JR, McFadgen BG 2002. Seismic driving of nationwide changes in geomorphology and prehistoric settlement—a 15th Century New Zealand example. Quaternary Science Reviews 21(20-22): 2229-2236.

Goff, JR, Wells, A, Chagué-Goff, C, Nichol, SL, Devoy, RJN 2004. The elusive AD 1826 tsunami, South Westland, New Zealand. New Zealand Geographer 60(2): 28-39.

Goff, JR, Lane, E, Arnold, J 2009. The tsunami geomorphology of coastal dunes. Natural Hazards and Earth System Sciences 9: 847-854, doi:10.5194/nhess-9-847-2009.

Hatton, L, Worthingon, MH, Makin, J 1986. Seismic Data Processing: Theory and Practice. Oxford, Blackwell Scientific Publications. 177 p. 
Howarth, JD, Fitzsimons, SJ, Norris, RJ, Jacobsen, GE 2012. Lake sediments record cycles of sediment flux driven by large earthquakes on the Alpine Fault, New Zealand. Geology 40 (12): 1091-1094.

Hubbert, MK, Rubey, WW 1959. Role of fluid pressure in the mechanics of overthrust faulting. Bulletin of the Geological Society of America 70: 115-205.

Kanaswich, ER 1981. Time Sequence Analysis in Geophysics. 3rd edition. Edmonton, University of Alberta Press. 483 p.

Loke, MH, Barker, RD 1996. Rapid least-squares inversion of apparent resistivity pseudosections by a quasi-Newton method. Geophysical Prospecting 44: 131-152.

Meyers, RA, Smith, DG, Jol, HM, Peterson, CD 1996. Evidence for eight great earthquakesubsidence events detected with ground-penetrating radar, Willapa barrier, Washington.

Geology 24: 99-102.

Milsom, J, Erisken, A 2011. Field Geophysics. 4th edition. Chichester, Wiley \& Sons. 287 pp.

Morley, CK 2007. Development of crestal normal faults associated with deepwater fold growth. Journal of Structural Geology 29: 1148-1163.

Nobes, DC, Ferguson, RJ, Brierley, GJ 2001. Ground-penetrating radar and sedimentological analysis of Holocene floodplains: insight from the Tuross valley, New South Wales. Australian Journal of Earth Sciences 48: 347-355.

Norris, RJ, Cooper, AF 2001. Late Quaternary slip rates and slip partitioning on the Alpine fault, New Zealand: Journal of Structural Geology 23: 507-520. doi: 10.1016/S01918141(00)00122-X.

Patton JR, Goldfinger C, Morey A, Erhardt M, Black B, Garrett A, Djadjadihardja Y, Hanifa U 2009. 7.5 KA Earthquake recurrence history in the region of the 2004 Sumatra-Andaman earthquake. GSA Annual Meeting, Paper No. 154-8. 
Peterson, CD, Jol, HM, Vanderbergh, S, Phipps, JB, Percy, D, Gelfenbaum, G 2010. Dating of late Holocene beach shoreline positions by regional correlation of coseismic retreat events in the Columbia Rover littoral cell, USA. Marine Geology 273: 44-61.

Quigley MC, Sandiford M, Cupper ML 2007. Distinguishing tectonic from climatic controls on range-front sedimentation. Basin Research 19(4): 491-505.

Rattenbury, MS, Jongens, R, Cox, SC 2010. Geology of the Haast Area. GNS Science, Lower Hut, New Zealand. Institute of Geological \& Nuclear Sciences 1:250 000 Geological Map 14.

Robinson TR, Davies TRH 2013. Potential geomorphic consequences of a future great $(\mathrm{Mw}=$ 8.0+) Alpine Fault earthquake, South Island, New Zealand. Natural Hazards and Earth System Sciences 13: 2279-2299.

Sircombe, KN, Kamp, PJJ 1998. The South Westland Basin: seismic stratigraphy, basin geometry and evolution of a foreland basin within the Southern Alps collision zone, New Zealand. Tectonophysics 300 (1-4): 359-387.

Smith, DG, Meyers, RA, Jol, HM 1999. Sedimentology of an upper-mesotidal (3.7 m) Holocene barrier, Willapa Bay, SW Washington, USA. Journal of Sedimentary Research 69 (6): 1290-1296.

Srinivasalu, S, Thangaduraia, N, Switzerb, AD, Mohanc, VR, Ayyamperumal, T 2007. Erosion and sedimentation in Kalpakkam (N Tamil Nadu, India) from the 26th December 2004 tsunami. Marine Geology 240: 65-75, doi:10.1016/j.margeo.2007.02.003.

Sutherland, R 1996. Transpressional development of the Australia_Pacific boundary through southern South Island, New Zealand: Constraints from Miocene_Pliocene sediments, Waiho _1 borehole, South Westland. New Zealand Journal of Geology and Geophysics 39 (2): 251264.

Taner, MT 2001. Seismic attributes. CSEG Recorder, 26 (7): 48-56. 
DC Nobes et al.

Taner, MT, Koehler, F, Sheriff, RE 1979. Complex seismic trace analysis. Geophysics, 44: $1041-1063$.

Wang J, Jin Z, Hilton RG, Zhang F, Densmore AL, Li G, West AJ 2015. Controls on fluvial evacuation of sediment from earthquake-triggered landslides. Geology 43: 115-118.

Wells, A, Goff, J 2006. Coastal dune ridge systems are chronological markers of palaeoseismic activity: a 650-yr record from southwest New Zealand. The Holocene 16 (4): 543-550.

Wells, A, Goff, J 2007. Coastal dunes in Westland, New Zealand, provide a record of paleoseismic activity on the Alpine Fault. Geology 35 (8): 731-734.

Yetton, MD, Nobes, DC 1998. Recent vertical offset and near-surface structure of the Alpine Fault in Westland, New Zealand, from ground penetrating radar profiling. New Zealand Journal of Geology and Geophysics 41: 485-492. 
Subsurface imaging of disrupted stratigraphy, South Westland, New Zealand

\section{Figures}

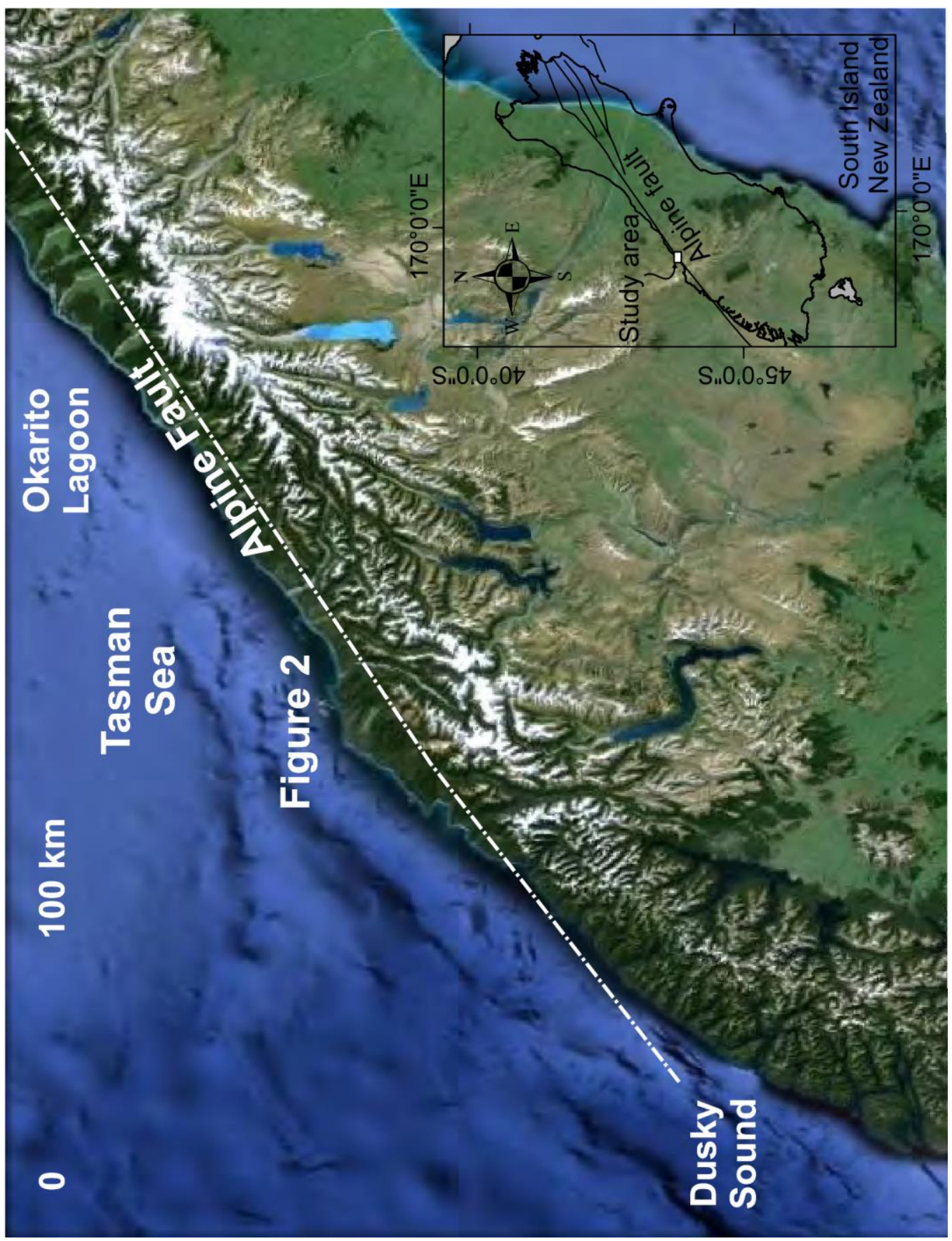

Figure 1. The study site was in South Westland, near the Alpine Fault. The 1826 tsunami was observed in Dusky Sound, about $200 \mathrm{~km}$ south of our study site, and deposits of that tsunami have been found in Okarito Lagoon, about $100 \mathrm{~km}$ north of our study site. Inset: Location of the study area on the West Coast of the South Island. 


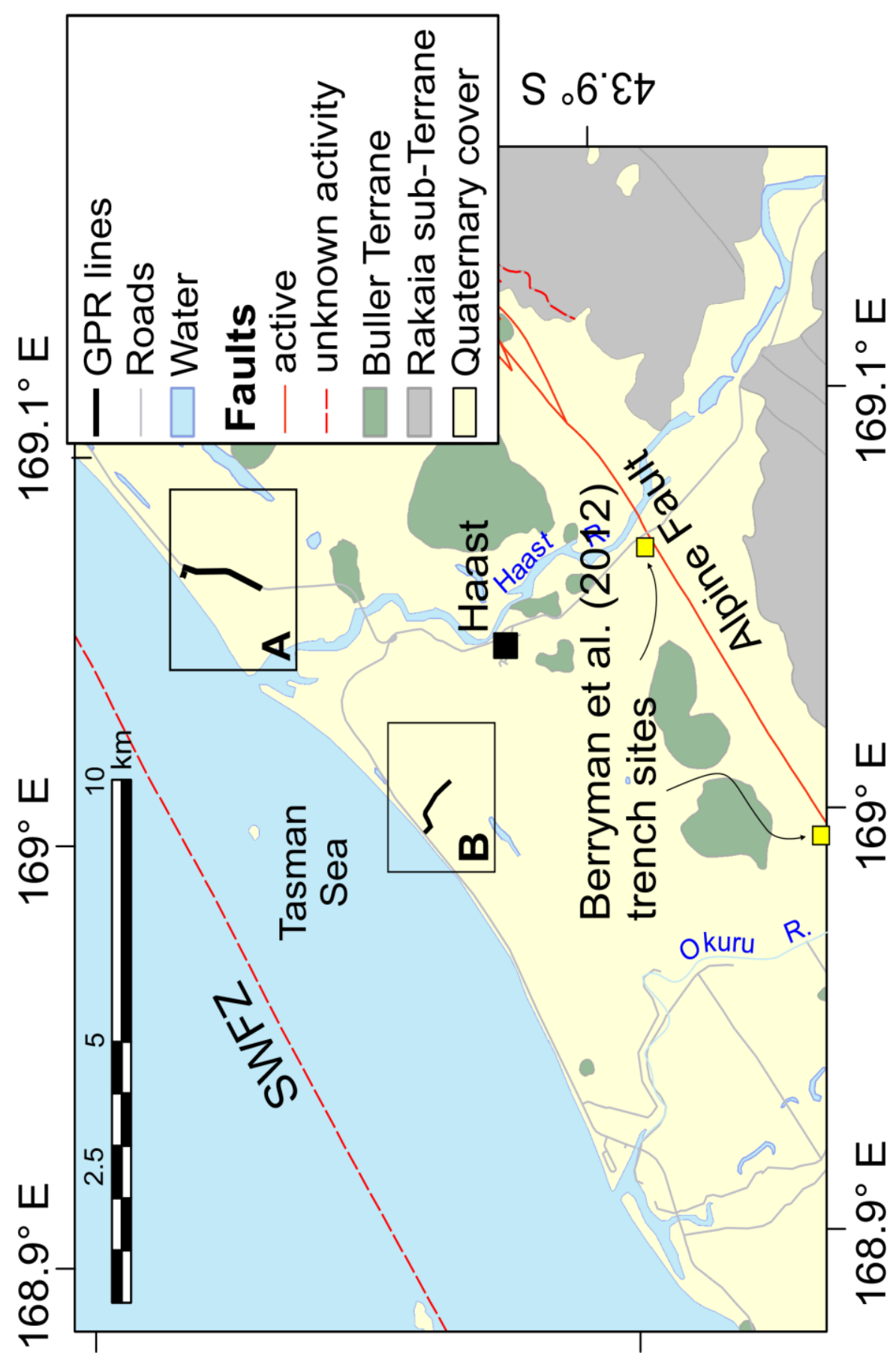

Figure 2. The study location was northwest of the Alpine Fault and southeast of the offshore South Westland Fault Zone (SWFZ). One site was near the mouth of the Haast Rivers (A) and a second between the Haast and Okuru River mouths (B). The Haast profile was acquired in two segments: a shoreward segment running from the highway to the high tide marks, and along the roads. 

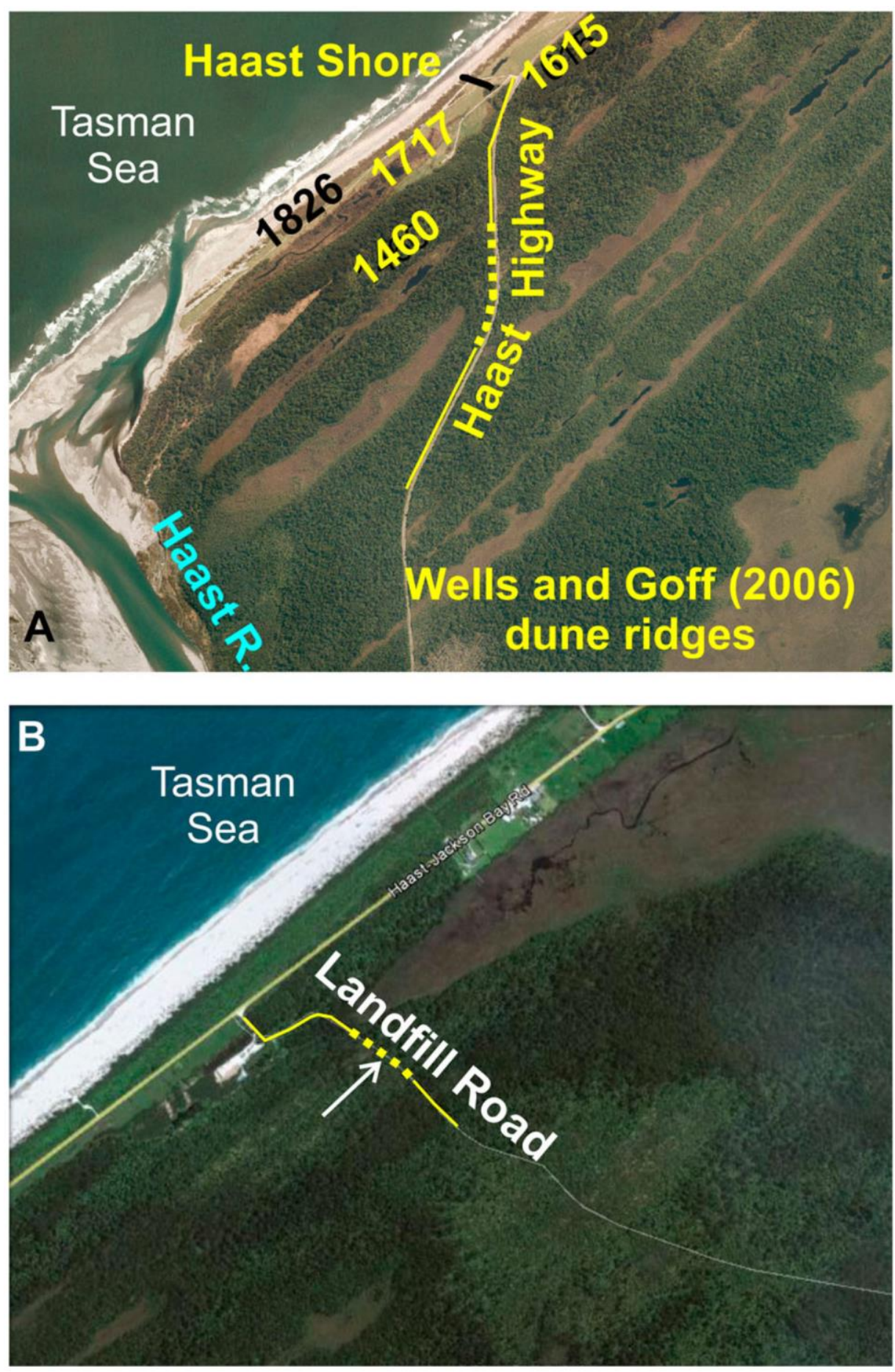

Figure 3. Detailed views of the two survey locations. (A) The Haast shore and Haast Highway profile locations are northeast of the Haast River mouth. The dune ridge dates from the Wells and Goff (2006) model are shown for reference. (B) The Haast landfill road profile started next to the highway and then followed an old supply track. The location of the stream cut noted in the text and in Figures 12 and 13 is indicated by the arrow. 
DC Nobes et al.

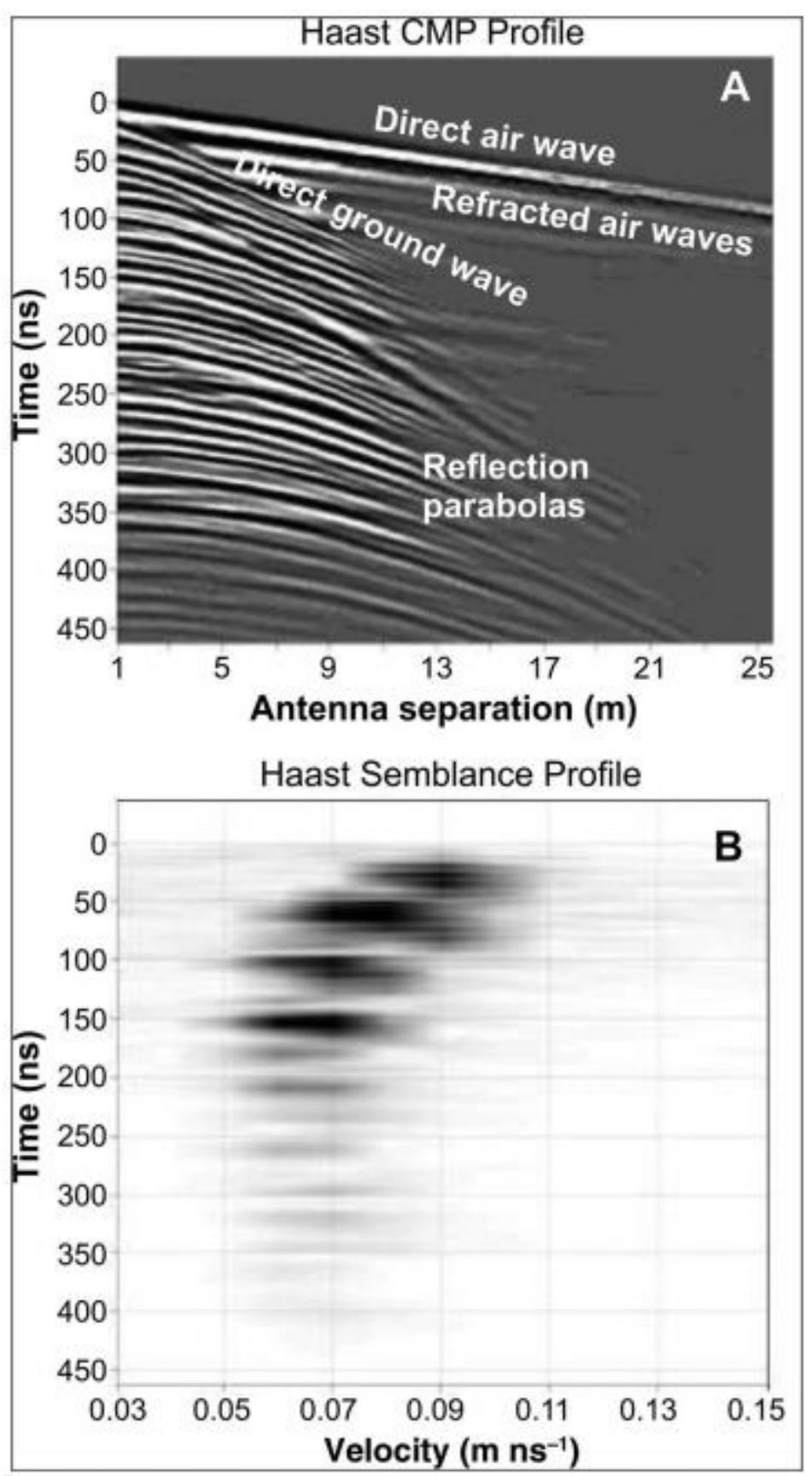

Figure 4: The Haast CMP profile (A, top) had no clear direct ground arrival. The air arrival yields a velocity of $0.3 \mathrm{~m} / \mathrm{ns}$, as it should, which calibrates the profile. The resultant semblance analysis (B, bottom) yields velocities that decrease from $0.09 \mathrm{~m} / \mathrm{hs}(90 \mathrm{~m} / \square \mathrm{s})$ in the upper $50 \mathrm{~ns}$, to about $0.07 \mathrm{~m} / \mathrm{ns}(70 \mathrm{~m} / \mathrm{\square s})$ below $50 \mathrm{~ns}$. 
Subsurface imaging of disrupted stratigraphy, South Westland, New Zealand
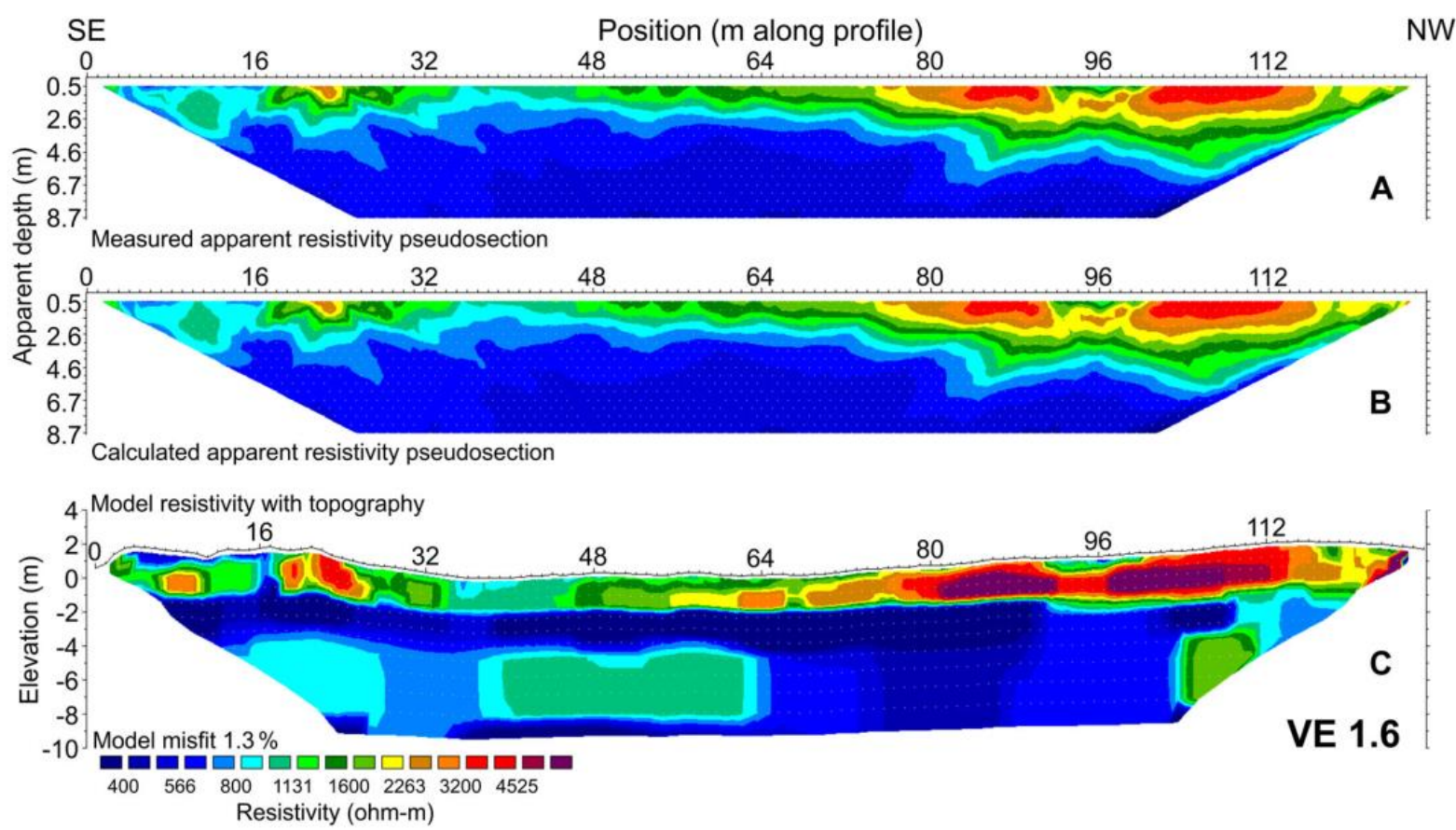

Figure 5. The measured apparent electrical resistivity for the HRM EI profile (A) has a good "best fit" model response (B) that yields a misfit of only $1.3 \%$. The "best-fitting" model including topography $(\mathbf{C})$ has a high-resistivity layer on the top, corresponding to the sand dunes on the surface, and lower resistivity layers and features at depth. 

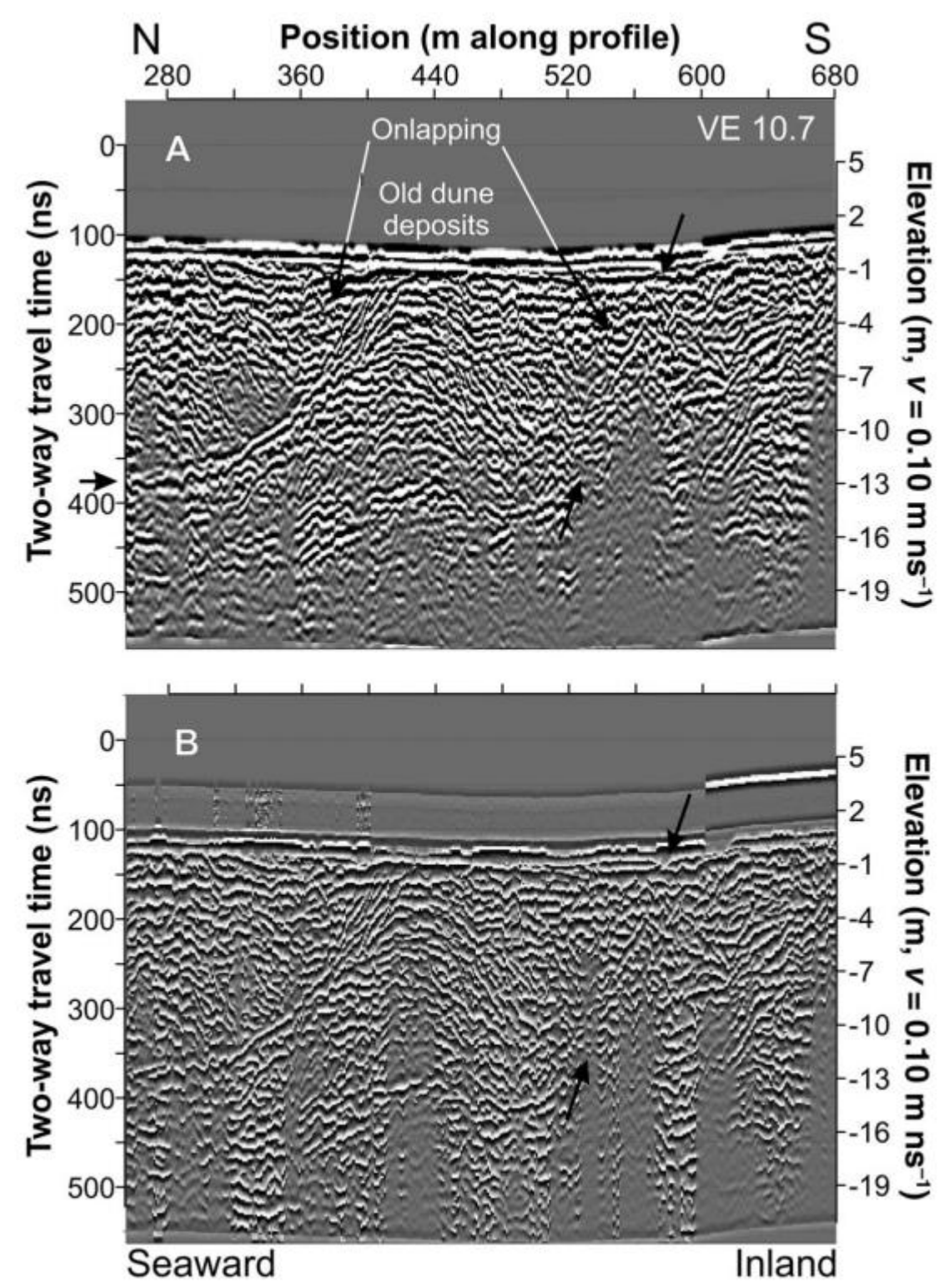

Figure 6. A portion of the migrated and topographically corrected Haast Highway profile (A) and the instantaneous phase (B) illustrates some characteristic features. The profiles are viewed as if looking from the southwest to the northeast; the sea is to the northwest. The dune is visible, centred at about $440 \mathrm{~m}$ along the profile. The steepness of the dune face at shallow depths may suggest a storm beach front. At about $560 \mathrm{~m}$ along the profile, we see truncated beds, and some possibly hummocky reflections at depth at about $480 \mathrm{~m}$ along the profile. This feature could be a storm beach or a slump of sediment triggered by a storm or some other cause. 

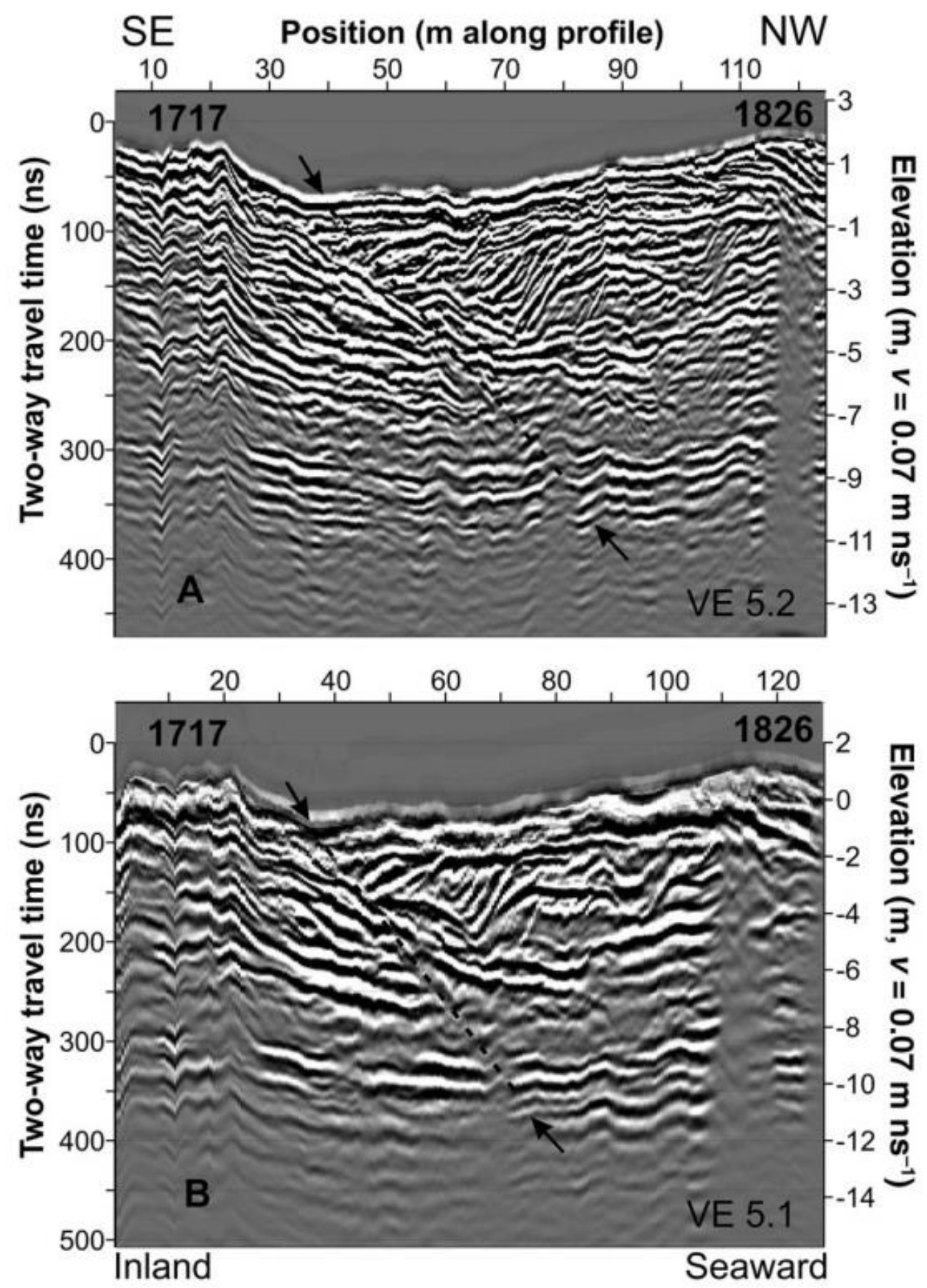

Figure 7. The $100 \mathrm{MHz}(\mathbf{A})$ and $50 \mathrm{MHz}(\mathbf{B}) \mathrm{HRM}$ profiles appear to have a feature that not only truncates the beds, but also appears to disrupt the wave base at $300-350$ ns TWT (about $11 \mathrm{~m}$ depth). The feature is clearest in the $50 \mathrm{MHz}$ profile (B). The profiles run approximately southeast to northwest. The profiles are viewed as if looking from the northeast to the southwest, with the sea to the northwest. 

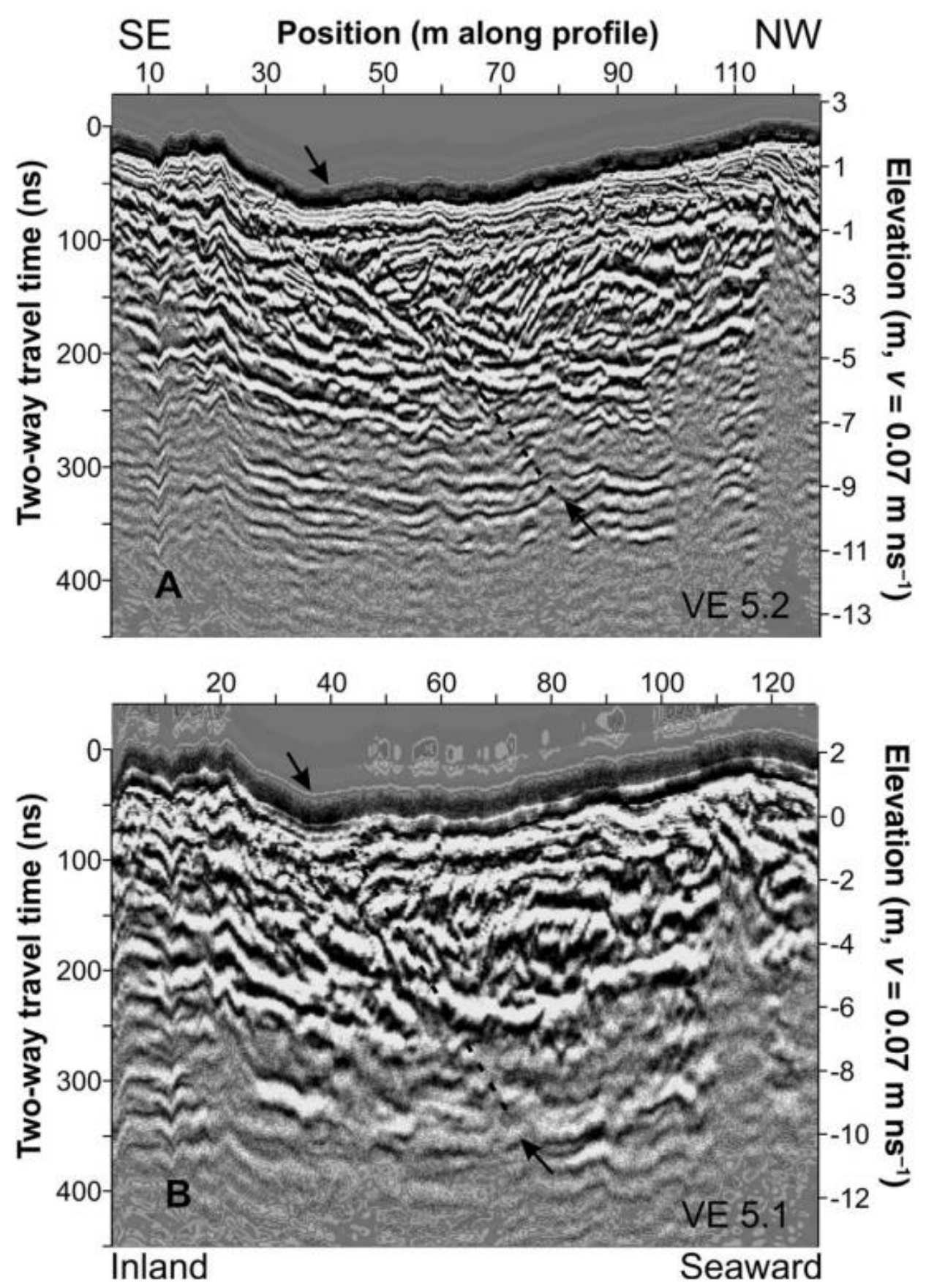

Figure 8. The envelope enhances the changes observed across the truncating feature in the 100

MHz HRM profile (A). The reflections either side of the feature are clearly different.

The changes are not so enhanced in the $50 \mathrm{HRM}$ MHz profile (B), where the normal GPR profile (Fig. 7B) more clearly shows the presence of the truncating feature. 

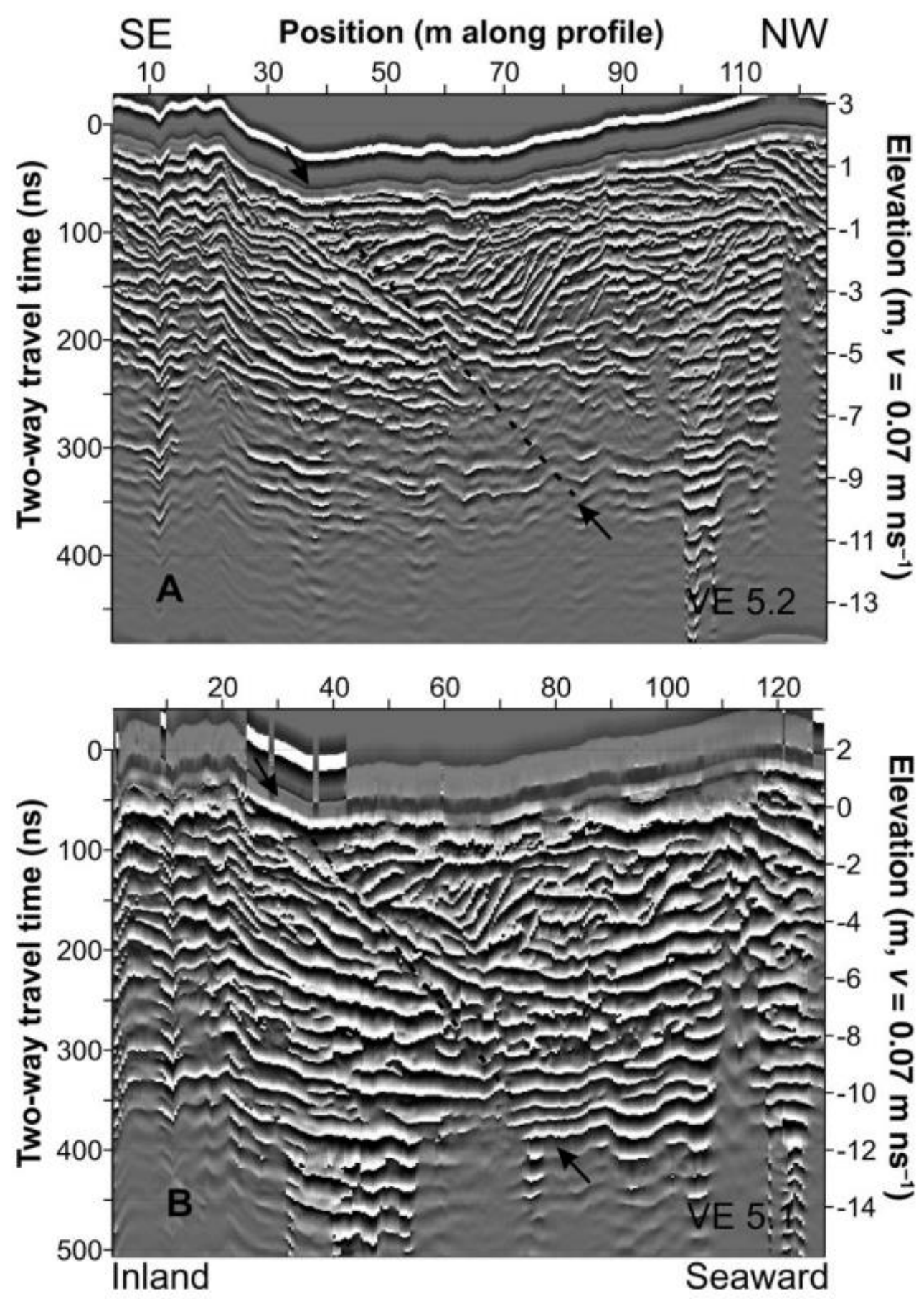

Figure 9. The instantaneous phase profiles corresponding to those in Figure 8 are shown for the $100 \mathrm{MHz}$ HRM profile (A) and $50 \mathrm{MHz}$ profile (B). In this case, the linear feature noted in Figure 8 is more clearly seen in the $100 \mathrm{MHz}$ instantaneous phase (A). 

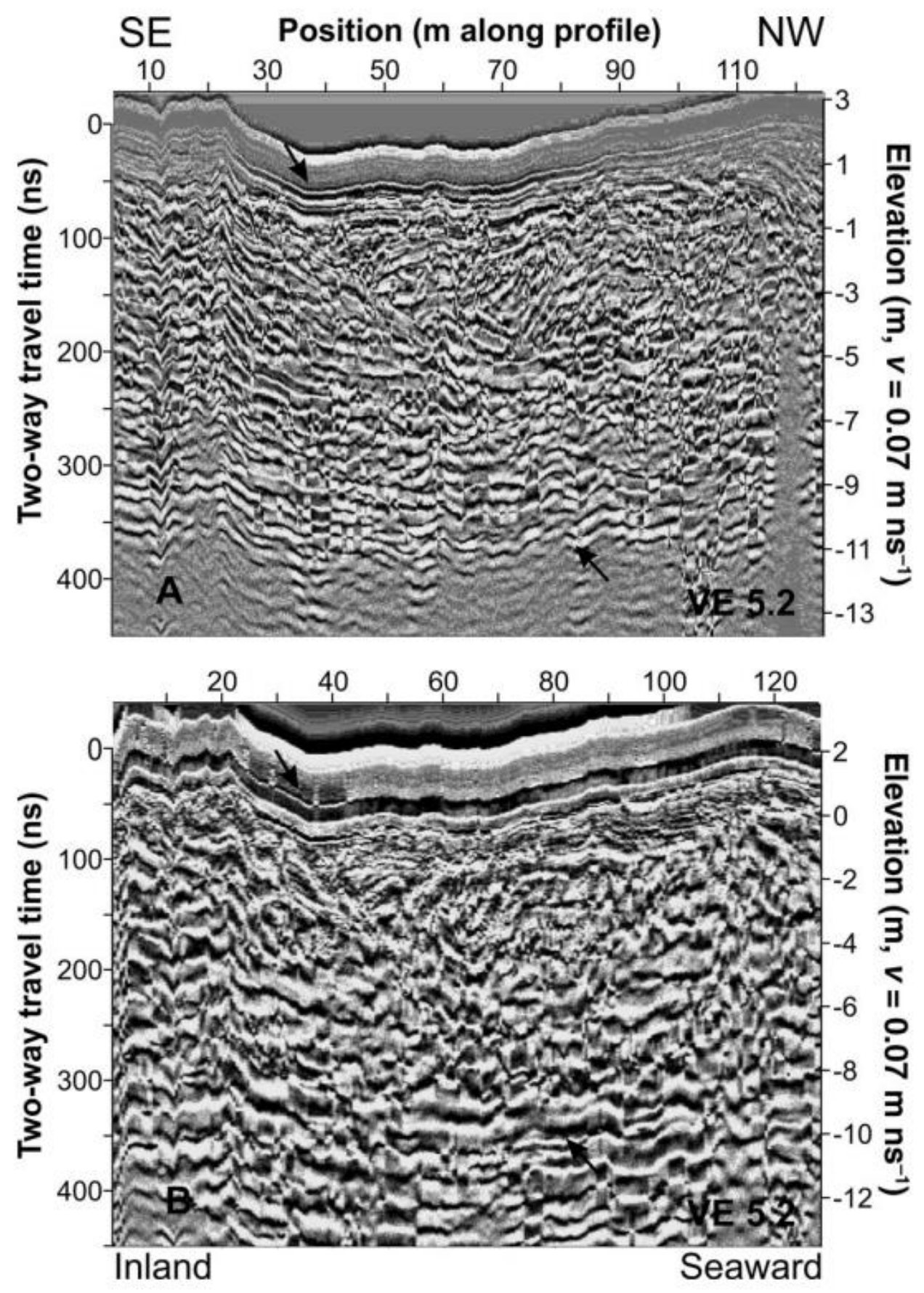

Figure 10. The instantaneous frequency shows only minor changes across the possible structure. The differences in the textural response is greater at depth in the $100 \mathrm{MHz} \mathrm{HRM}$ profile (A), below about 60 to $80 \mathrm{~m}$ along the profile. As for the envelope (Fig. 8B) and instantaneous phase (Fig. 9B), the instantaneous frequency for the $50 \mathrm{MHz}$ HRM profile $(\mathbf{B})$ does not enhance the response of the truncating feature. 

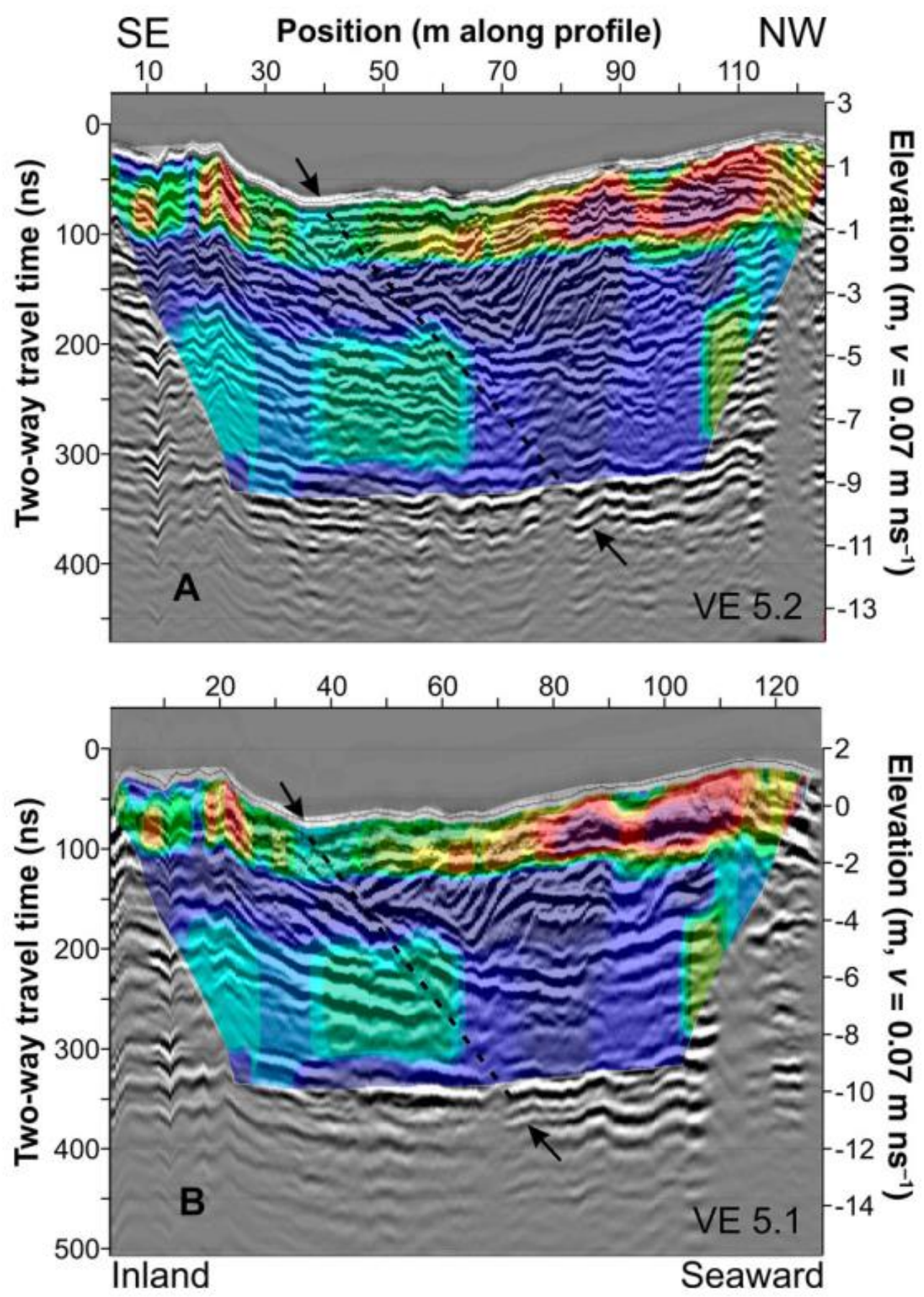

Figure 11. The HRM GPR $100 \mathrm{MHz}(\mathbf{A})$ and $50 \mathrm{MHz}$ (B) profiles are shown overlain with the best-fitting resistivity model. A truncating feature is readily apparent and has a clear influence on the subsurface electrical properties as well as on the GPR. 

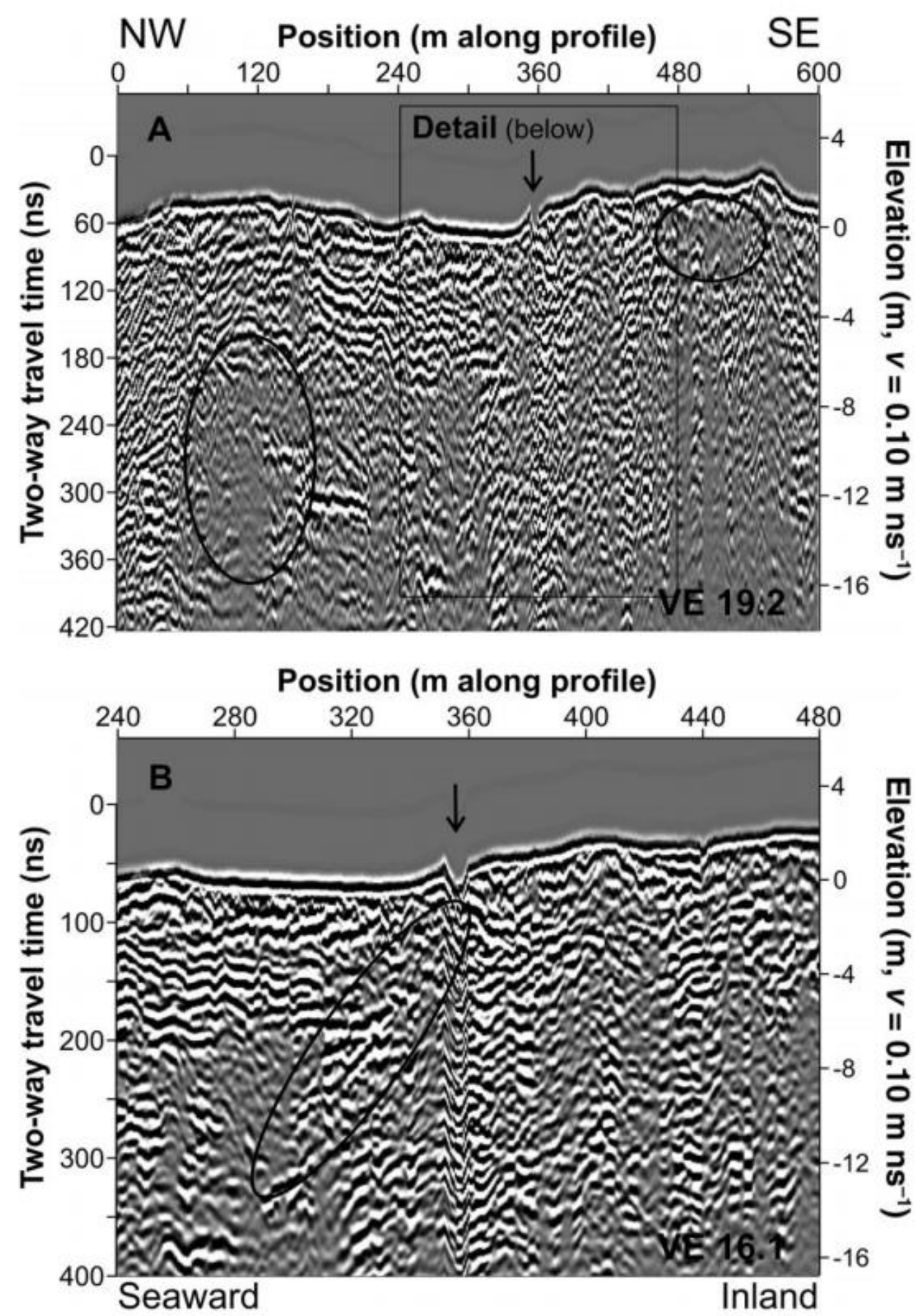

Figure 12. The HLR profile (A) and a detailed section from 240 to $480 \mathrm{~m}$ along the HLR profile (B) highlight near surface coastal dune features, and a possible truncating feature dipping to the northwest, which comes to surface at an incised stream channel. 

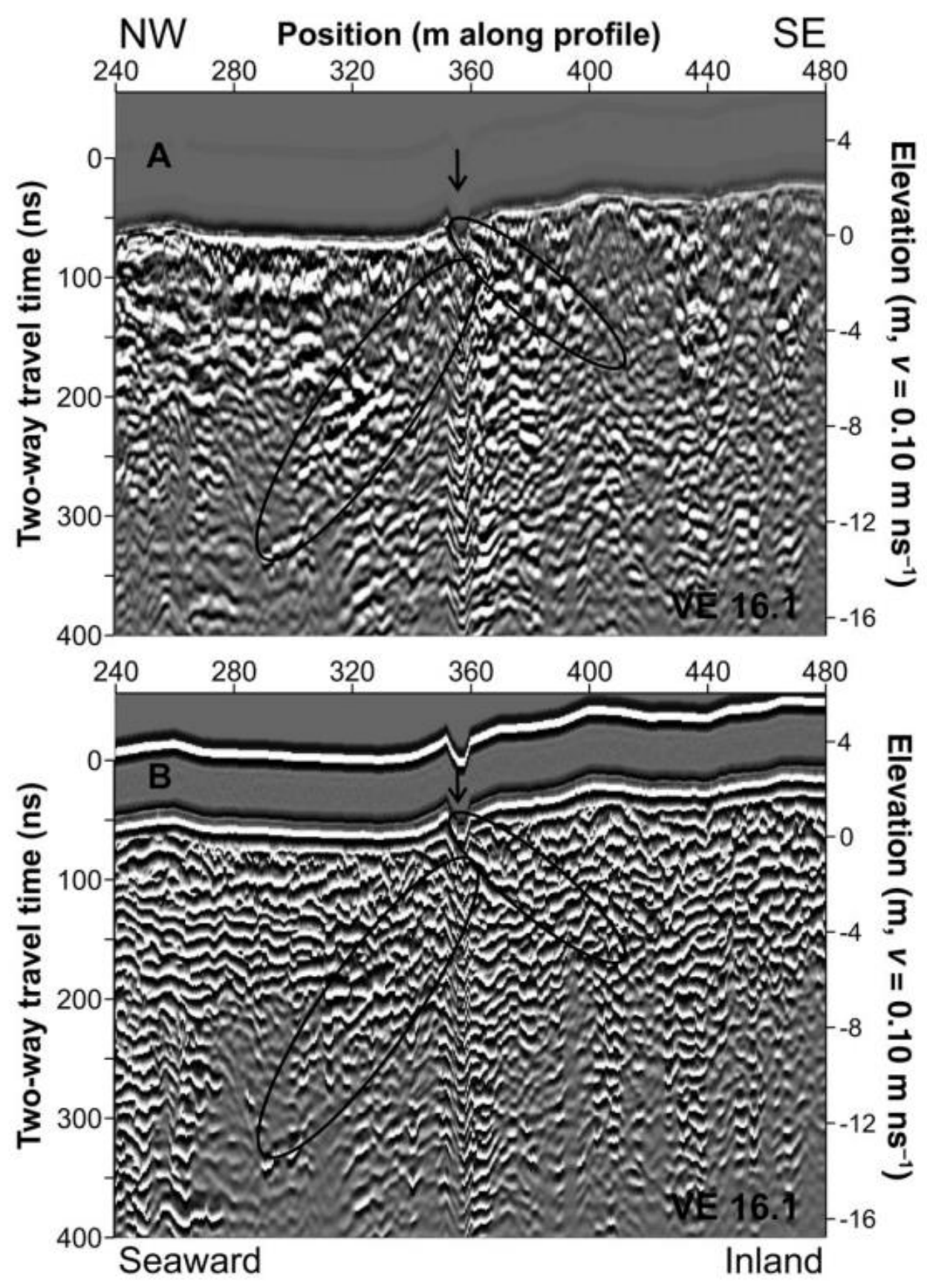

Figure 13. The complex attributes envelope (A) and instantaneous phase (B) of the subset of the HLR profile shown in Fig. 12B enhance the appearance of the truncating feature that reaches the surface at the stream cut (arrow). In addition, in the envelope response (B), there also appears to be a feature dipping inland (to the right) to the southeast away from near the crest of the stream cut. 


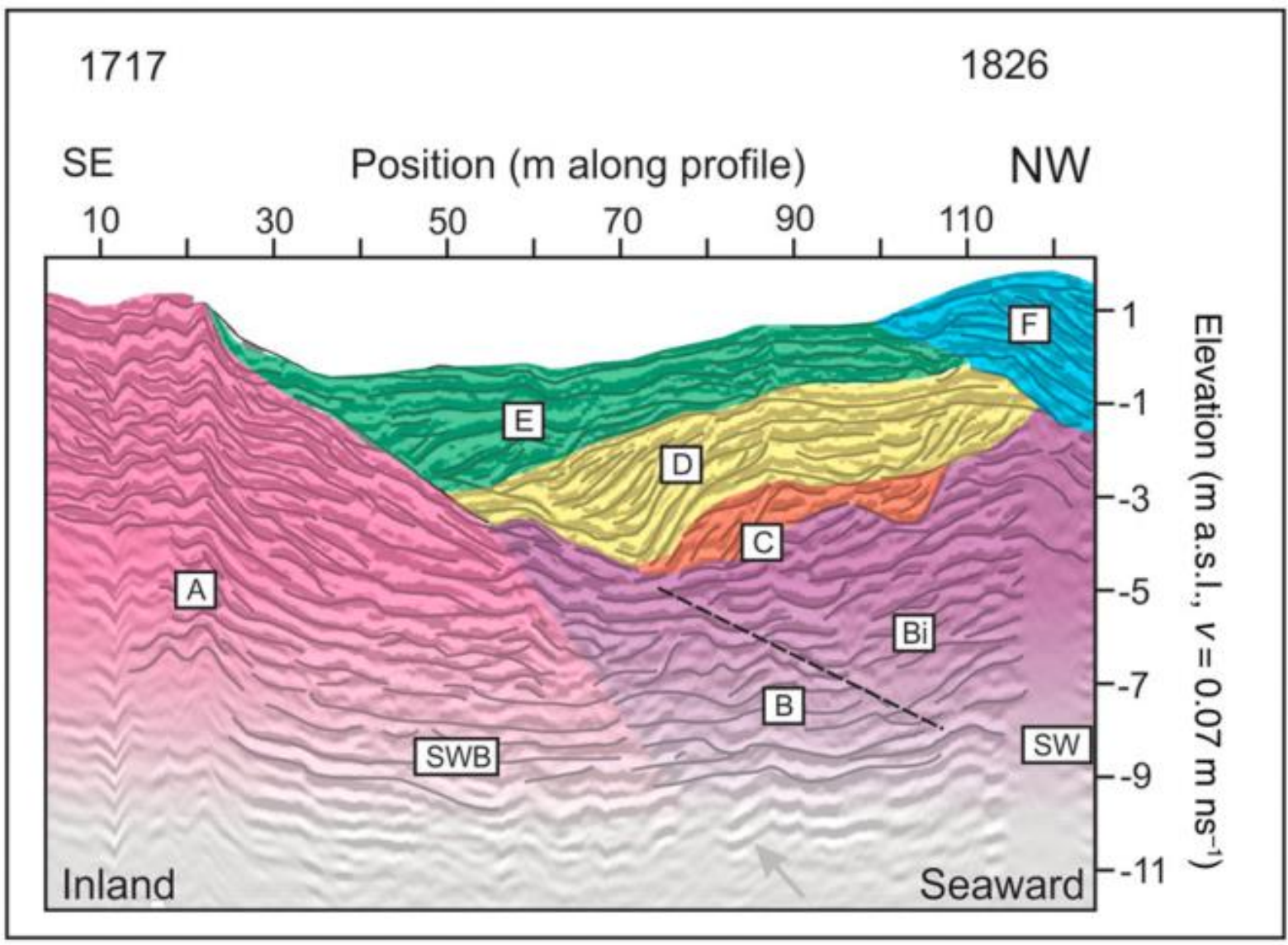

Figure 14. An interpretive diagram incorporating the reflections observed along all of the HRM profiles. The 1717 dune deposits (A) overlie the storm wave base (SWB), and are truncated by the feature noted in the text and in Figures 10 through 13 . Some of the material eroded from A was initially deposited (B) at the base of the 1717 dune deposits. The start of the deposition in the aftermath of the 1826 event then built coastal dune foresets (Bi), followed by cycles of sediment accretion (C, D and E). Finally, the dune foreslope sediments were deposited (F). Sea water (SW) impedes penetration of the radar signal. 


\section{University Library}

\section{- M M N E R VA A gateway to Melbourne's research publications}

Minerva Access is the Institutional Repository of The University of Melbourne

Author/s:

Nobes, DC;Jol, HM;Duffy, B

Title:

Geophysical imaging of disrupted coastal dune stratigraphy and possible mechanisms, Haast, South Westland, New Zealand

Date:

2016-09-01

\section{Citation:}

Nobes, D. C., Jol, H. M. \& Duffy, B. (2016). Geophysical imaging of disrupted coastal dune stratigraphy and possible mechanisms, Haast, South Westland, New Zealand. NEW ZEALAND JOURNAL OF GEOLOGY AND GEOPHYSICS, 59 (3), pp.426-435. https:// doi.org/10.1080/00288306.2016.1168455.

Persistent Link:

http://hdl.handle.net/11343/113743 